\title{
KRONIKA
}

DARIUSZ STĘPKOWSKI

Wydział Nauk Pedagogicznych

Uniwersytet Kardynała Stefana Wyszyńskiego

Warszawa

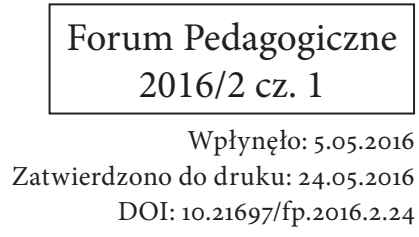

DOI: $10.21697 / \mathrm{fp} .2016 .2 .24$

\section{Seminarium Polskiej Myśli Pedagogicznej pt. „Realizm filozoficzny jako podstawa koncepcji i kierunków rozwoju polskiej myśli pedagogicznej" (Uniwersytet Jagielloński, Kraków, 29 kwietnia 2016 roku)}

Spotkania poświęcone polskiej myśli pedagogicznej zostały zainicjowane na Uniwersytecie Jagiellońskim przez Janinę Kostkiewicz w 2014 roku. Od samego początku inicjatywie tej towarzyszą dwa inne działania, a mianowicie, po pierwsze, wydawanie rocznika „Polska Myśl Pedagogiczna”, którego pierwszy numer ukazał się w roku 2015 i, po drugie, otwarcie w Wydawnictwie Uniwersytetu Jagiellońskiego serii wydawniczej opatrzonej tym samym tytułem. W serii tej również w 2015 roku ukazał się pierwszy tytuł, a mianowicie monografia Dominiki Jagielskiej i Janiny Kostkiewicz pt. Pedagogika humanizmu społecznego Andrzeja Niesiołowskiego. Wspólnym celem wymienionych działań jest przywrócenie pamięci, a właściwie odkrycie dziedzictwa polskich myślicieli (pedagogów i filozofów) w zakresie wychowania i kształcenia.

Organizatorami drugiego seminarium był kierowany przez J. Kostkiewicz Zakład Pedagogiki Szkoły Wyższej i Polskiej Myśli Pedagogicznej Instytutu Pedagogiki Uniwersytetu Jagiellońskiego i Stowarzyszenie Studentów i Absolwentów „Paideia”. Na miejsce obrad została wybrana sala im. M. Bobrzyńskiego w Collegium Maius Uniwersytetu Jagiellońskiego. Spotkanie zgromadziło około 30 przedstawicieli ośrodków naukowych z całej Polski. Uroczystego otwarcia seminarium dokonał dziekana Wydziału Filozoficznego Jarosław Górniak, który nawiązując do tegorocznego tematu, zwrócił uwagę na odradzanie się nastawienia realistycznego we współczesnej nauce. Jako przykład podał swoją własną dyscyplinę - ekonomię, w której badania empiryczne niejako z konieczności domagają się realizmu poznawczego.

W programie obrad można było wyodrębnić trzy elementy: wykład wprowadzający, trzy sesje tematyczne i dwie dyskusje panelowe - przed obiadem i na zakończenie. Wykład wprowadzający wygłosił Andrzej Maryniarczyk z Katolickiego Uniwersytetu Lubelskiego Jana Pawła II. Tytuł jego wystąpienia brzmiał: Antropologiczno-metafizyczne podstawy adekwatnej teorii wychowania w ujęciu twórców Filozoficznej Szkoły Lubelskiej. Punktem wyjścia do rozważań była konstatacja, że pedagogika mając do czynienia z żywym człowiekiem, domaga 
się realistycznego spojrzenia na jego możliwości i ograniczenia. Takie spojrzenie może, zdaniem prelegenta, zagwarantować tylko równoczesne uwzględnienie dwóch nauk: metafizyki rozumianej jako „nauka czytania rzeczywistości”, co wskazuje na potrzebę umiejętnego intepretowania świata rzeczy, i antropologii, której zadaniem jest poznanie człowieka. Dominujące współcześnie jednostronne zainteresowanie pedagogiki wyłącznie antropologią filozoficzną referent ocenił jako zawężenie problematyki wychowania.

W kolejnym kroku A. Maryniarczyk wyjaśnił pojęcia: „podmiot”, „natura” i „działanie”. Jego zdaniem wyznaczają one perspektywę, z której należy nie tylko intepretować to, kim jest człowiek, lecz również obmyślać jego wychowanie. Słuchacze nie mogli oprzeć się wrażeniu, że referent traktuje pedagogikę tylko jako naukę aplikacyjną. Potwierdzeniem tego była część referatu, w której mówca dokonał rozróżnienia między stanowiskiem realistycznym i idealistycznym w pedagogice, zakładając, że każde z nich wynika z przyjętych założeń filozoficznych. $\mathrm{Na}$ tym tle przedstawił wkład twórców Lubelskiej Szkoły Filozoficznej w kształtowanie głównego pojęcia pedagogiki realistycznej, jakim jest „osoba”.

Kończąc swoje wystąpienie, A. Maryniarczyk zwrócił uwagę na zadanie antropologii adekwatnej - podejmowanie działań umożliwiających człowiekowi osiągnięcie takiego poziomu rozwoju, jaki wyznacza mu metafizyczna wizja osoby. Urzeczywistnienie tego celu musi jednak dokonywać się przez doświadczenie pedagogiczne. O ile to pierwsze - cel - jest z góry zdeterminowany, o tyle sposobowi dotarcia do niego przysługuje atrybut niezdeterminowania. Wypełnienie swoistej luki, jaka tutaj powstaje, należy do zadań pedagogiki.

Po wykładzie wprowadzającym rozpoczęła się pierwsza sesja tematyczna. Organizatorzy nadali jej tytuł Tradycja i dorobek polskich kierunków i koncepcji pedagogicznych opartych na realizmie filozoficznym. Wysłuchano pięciu wystąpień. Obradom zaś przewodniczyli Janina Kostkiewicz i Stanisław Palka.

Jako pierwszy zabrał głos Marek Rembierz z Uniwersytetu Śląskiego, który zaprezentował temat: Realizm metafizyczny jako inspiracja myśli pedagogicznej. O refleksji antropologiczno-pedagogicznej Stefana Swieżawskiego (współtwórcy szkoły lubelskiej) i jej miejscu w polskiej teorii wychowania. Mottem swoich rozważań prelegent uczynił fragment pochodzący z pracy S. Swieżawskiego pt. Święty Tomasz na nowo odczytany, w którym autor uzależnił poznanie człowieka, a w szczególności siebie samego, od poznania świata zwierząt. Według M. Rembierza, to pozorne odwrócenie porządku myślenia należy odczytywać jako wezwanie do realizmu skierowane (również) do pedagogiki. Wyjaśniając dalej, prelegent stwierdził, że wybitnemu znawcy filozofii Tomaszowej nie chodziło bynajmniej o przeciwstawienie sobie świata zwierząt i świata ludzi, lecz o eksperyment myślowy, w którym człowiek staje się zdolny do poznania tego, kim właściwie jest, przez alienację polegającą na zderzeniu z tym, czego nie zna. Stając ze zdziwieniem wobec rzeczywistości niejako przedludzkiej, odkrywa siebie samego. Tak rozumiany realizm stawia przed pedagogiką zadanie prowadzenia procesu wychowania i kształcenia 
w taki sposób, żeby rozwijający się człowiek nie tylko nie stracił zdolności do doświadczania zdziwienia, lecz wręcz przeciwnie - formował ją w sobie jako drogę do samopoznania.

W kolejnym referacie Maria M. Boużyk z Uniwersytetu Kardynała Stefana Wyszyńskiego w Warszawie omówiła temat: Realizm filozoficzny Szkoły Lubelskiej jako podstawa modelu wychowania otwartego na religię. Osią jej rozważań był interdyscyplinarny model wychowania do świętości, którego filozoficzne podwaliny położyli twórcy Lubelskiej Szkoły Filozoficznej.

Następnie głos zabrała Danuta Opozda z Katolickiego Uniwersytetu Lubelskiego Jana Pawła II, która scharakteryzowała Kierunek rozwoju pedagogiki rodziny wyznaczony realizmem filozoficznym szkoły lubelskiej. Jej analiza dotyczyła kreowania się instytucjonalnej i dyscyplinarnej specyfiki pedagogiki rodziny jako odrębnej subdyscypliny pedagogicznej na KUL JP II.

Dalej zebrani wysłuchali referatu Andrzeja Ryka z Uniwersytetu Pedagogicznego w Krakowie. Prelegent przedstawił temat: Elementy realizmu i idealizmu klasycznego w pedagogii polskiej Władysława Seredyńskiego. Jego zdaniem dorobek wymienionego w tytule autora warty jest przypomnienia $\mathrm{z}$ wielu względów. Jednym z nich jest wyraźnie obecne w pismach Seredyńskiego dążenie do odkrycia w wychowaniu tego, co można by opatrzyć mianem „filozoficzne”. Fałszywe teorie wychowania jego czasów wynikały przede wszystkim z błędnego zrozumienia natury wychowania, jego celów i środków. Postawy realistycznej nie wyprowadzał on z przyjmowanych założeń filozoficznych, lecz z trafnie ujmowanego sensu wychowania.

Pierwszą sesję zakończył Witold Starnawski z Uniwersytetu Kardynała Stefana Wyszyńskiego w Warszawie, który podjął temat wyrażony za pomocą pytania: Czym jest realizm $w$ pedagogii osoby? Odpowiadając na nie, prelegent postulował przeprowadzenie korekty w kierunku myślenia. Jego zdaniem bowiem „realizm nie jest celem działań wychowawczych, lecz niezbędnym warunkiem; celem jest natomiast pomoc w doskonaleniu się osoby". Wyjaśniając dalej swoje stanowisko, stwierdził, że „realizm w przypadku osoby oznacza przyjęcie jej subiektywności, wewnętrzności jej bytu". Stąd świat subiektywny (wewnętrzny) należy nie tylko uwzględnić w pojęciu realizmu, lecz nawet uznać za pierwotny i zasadniczy. Tak więc - zdaniem W. Starnawskiego - „kategoria prawdy wydaje się w pedagogii (pedagogice) bardziej adekwatna niż kryterium realizmu, gdyż pozwala lepiej i głębiej spojrzeć na wychowanie jako proces wspierania w doskonaleniu się osoby”.

Po krótkiej przerwie przystąpiono do drugiej sesji, która była zatytułowana „Teoretyczne i metodologiczne problemy realistycznej myśli pedagogicznej i pedagogiki”. Obradom przewodniczyli Katarzyna Olbrycht z Uniwersytetu Śląskiego i Dariusz Stępkowski z Uniwersytetu Kardynała Stefana Wyszyńskiego w Warszawie. W tej sesji - tak jak w poprzedniej - zostało przedstawionych również pięć referatów. Jako pierwszy głos zabrał Stanisław Palka z Uniwersytetu Jagiellońskiego, który podjął temat: Metodologiczny kontekst uprawiania pedagogiki realistyczno-konstruktywnej. Mówca wychodząc od konieczności łączenia 
w badaniach pedagogicznych aspektu teoretycznego i empirycznego, postawił pytanie o charakter zależności między praktyką a teorią w pedagogice realistycznej. Postulował konstruktywne uprawianie przez nią obu obszarów - teoretycznego i praktycznego. Jego zdaniem namysłowi pedagogicznemu tylko wówczas przysługuje cecha konstruktywności, gdy afirmując różnicę między teorią a praktyką, poszukuje implikacji spełniających kryterium słuszności, jakim jest doświadczenie nauczycieli-praktyków. Konkludując, mówca wskazał na potrzebę badawczego podejścia do oferty pedagogiki realistycznej, w tym chrześcijańskiej czy katolickiej, która swoje aspiracje winna potwierdzać badaniami pedagogicznymi.

Krzysztof Maliszewski z Uniwersytetu Śląskiego zaprezentował temat: Niekoniecznie realizm - uwagi krytyczno-metodologiczne. Mówca uwypuklił trzy pułapki, jakie jego zdaniem czyhają na badaczy bezrefleksyjnie posługujących się dychotomicznym podziałem: realizm versus idealizm. Są to w szczególności: 1) nadmierne skupieniu uwagi na teorii, a nie na badanej rzeczy; 2) pomijanie wbrew deklaracjom - kluczowych kwestii, takich jak: co to jest rzeczywistość?, jaki jest udział podmiotu w poznawaniu rzeczywistości?, w jaki sposób język i narracja współtworzą rzeczywistość? i 3) ideologizacja własnego stanowiska wyrażająca się m.in. w reagowaniu z oburzeniem na głosy niezgodne $\mathrm{z}$,jedynie słusznymi” poglądami.

Jako trzeci zabrał głos pochodzący również z Uniwersytetu Śląskiego Krzysztof Śleziński. Tytuł jego wystąpienia brzmiał: Założenia realizmu ontologicznego i aksjologicznego w koncepcji wychowania Jacka Woronieckiego. Mówca w obrazowy sposób przybliżył filozoficzne przesłanki działania pedagogicznego w ujęciu wymienionego w tytule autora. W kontekście wystąpienia piszącemu te słowa nasunęła się refleksja, którą ośmiela się podzielić z Czytelnikiem: o ile o J. Woronieckim można powiedzieć, że był pedagogizującym filozofem, o tyle w przypadku prelegenta kierunek tej zależności jest odwrotny - filozofujący pedagog. Czy nie mamy tu do czynienia z (nieuprawnionym?) przekraczaniem granic własnej dyscypliny naukowej?

W kolejnym wystąpieniu Mariusz Sztaba omówił temat: Realizm doświadczenia etycznego u podstaw adekwatnych koncepcji wychowania moralnego. Refleksja $w$ świetle etycznego personalizmu Karola Wojtyły i jego uczniów. Uznając wychowanie moralne za najstarszą i najbardziej rozpowszechnioną formę oddziaływania pedagogicznego, referent starał się uzasadnić konieczność budowania teorii tego wychowania w nawiązaniu do realistycznego podejścia do doświadczenia etycznego. To ostatnie wyjaśnił w oparciu o koncepcję personalizmu etycznego, wywodzącą się od Karola Wojtyły i kontynuowaną przez niektórych przedstawicieli Lubelskiej Szkoły Filozoficznej.

W drugiej sesji ostatnie wystąpienie było poświęcone stanowiskom realistycznym niewywodzącym się z Lubelskiej Szkoły Filozoficznej. Do takiej analizy zaprosił zabranych Michel H. Kowalewicz z Uniwersytetu Jagiellońskiego. Osią jego wywodów były wybrane spostrzeżenia odnoszące się do procesu kształtowania się 
polskiej terminologii pedagogicznej. Ograniczoność czasu, jaki miał do dyspozycji prelegent, nie pozwoliła na dogłębne przedstawienie tego ważnego skądinąd problemu.

Po wysłuchaniu omówionych powyżej referatów i krótkiej przerwie odbyła się dyskusja panelowa, którą poprowadziła gospodyni miejsca - Janina Kostkiewicz. Zaproszeni uczestnicy panelu zastanawiali się nad pytaniem: dlaczego realizm filozoficzny? Wprowadzeniem do tematu dyskusji było wystąpienie Tomasza Mioduszewskiego z Uniwersytetu Kardynała Stefana Wyszyńskiego w Warszawie, który zaproponował swoją odpowiedź na pytanie: Po co pedagogom metafizyka realistyczna? W trakcie panelu głos zabrali: Barbara Kiereś z Katolickiego Uniwersytetu Lubelskiego Jana Pawła II, Andrzej Ciążela z Akademii Pedagogiki Specjalnej im. M. Grzegorzewskiej w Warszawie i Andrzej Maryniarczyk z Katolickiego Uniwersytetu Lubelskiego Jana Pawła II.

Po przerwie na obiad kontynuowano obrady w sesji zatytułowanej: „Koncepcje pedagogiczne i ich związki z realizmem (lub/i idealizmem) - egzemplifikacje”. Prowadzenie tej części zostało powierzone Barbarze Kiereś i Ryszardowi Skrzyniarzowi (oboje z Katolickiego Uniwersytetu Lubelskiego Jana Pawła II). Jako pierwszy wystąpił niżej podpisany, który zaprezentował temat: Filozofia doświadczenia osobistego Stefana Z. Pawlickiego a pedagogika ogólna. Co prawda, analizowany autor nie był pedagogiem, jednak jego koncepcja nauki, a w szczególności idea powiązania myślenia filozoficznego z naukami szczegółowymi może - zdaniem prelegenta - być przetransponowana na grunt pedagogiki ogólnej w celu określenia jej specyficznego zdania tak w odniesieniu do filozofii, jak i subdyscyplin pedagogicznych. Wyjaśnienie tego było głównym przedmiotem omawianego wystąpienia.

W kolejnym referacie Maria Opiela z Katolickiego Uniwersytetu Lubelskiego Jana Pawła II wydobyła Znamiona realizmu w koncepcji pedagogicznej Edmunda Bojanowskiego oraz $w$ podstawach procesu jej zmian adaptacyjnych $i$ zachowania tożsamości. Jak podkreśliła prelegentka, realistyczna postawa twórcy ochronek nie wynikała z przyjętych a priori zasad teoretycznych, w tym filozoficznych, lecz z praktyki życiowej. Refleksja teoretyczna nad tą praktyką prowadzona jest dopiero współcześnie przy użyciu kategorii pojęciowych wypracowanych przez Lubelską Szkołę Filozoficzną.

Jarosław Horowski z Uniwersytetu Mikołaja Kopernika w Toruniu zaprezentował referat pt. Wstyd a rozwój moralny człowieka - o antropologicznych fundamentach pedagogiki neotomistycznej. Łamiąc stereotypowe podejście do neotomizmu, polegające na zawężaniu zakresu rozważanych problemów do tych, które w przeszłości podejmowali przedstawiciele tego nurtu filozoficznego, J. Horowski poddał analizie kategorię wstydu. Jak zaznaczył na wstępie, kategoria ta pojawia się rzadko w rozważaniach neotomistycznych. Po przywołaniu nielicznych fragmentów zaczerpniętych z pism Jacka Woronieckiego, Karola Górskiego i Karola Wojtyły, jak również Tomasza z Akwinu, przedstawił autorską próbę zinterpretowania tego pojęcia. Jego wystąpienie udowodniło zebranym, że refleksja pedagogiczna nie 
może ograniczać aplikowania gotowych odpowiedzi filozoficznych do praktyki wychowawczej, lecz może i powinna rozwijać się samodzielnie jako przynajmniej częściowo niezależny namysł nad zjawiskami należącymi do zakresu kompetencji pedagogiki. O tym, że nie jest to bynajmniej pogląd powszechny, przekonali się uczestnicy seminarium w trakcie kolejnego wystąpienia, w którym zaprezentowane zostało stanowisko całkowicie odmienne.

Anna Małdrzykowska przedstawiła Implikacje pedagogiczne realizmu filozoficznego Szkoły Lubelskiej. Referentka zgłosiła postulat „zwrotu ku metafizyce”. Jej zdaniem bowiem metafizyka całkowicie spełnia potrzeby pedagogiki i proponuje jej odpowiedzi na wszystkie pytania odnośnie do człowieka i jego rozwoju. Według A. Małdrzykowskiej, myślenie pedagogiczne jest wtórne i aplikacyjne. Jej zadaniem powinno być przede wszystkim wyciąganie właściwych wniosków z założeń filozoficznych. Dla zobrazowania tego mówczyni przedstawiła kilka wskazówek dla wychowania, wynikających, jak sądzi, z koncepcji Lubelskiej Szkoły Filozoficznej.

Jako następna głos zabrała Wiesława Sajdek z Akademii im. J. Długosza w Częstochowie. Prelegentka starała się odpowiedzieć na pytanie będące tytułem jej referatu: Jakiej filozofii pedagodzy potrzebują? O poczatkach pedagogiki uniwersyteckiej w Krakowie.

W kolejnym referacie Janusz Mółka z Akademii Ignatianum w Krakowie przedstawił temat: Personalizm chrześcijański fundamentem życiowego sukcesu. Po nim głos zabrał Marek Mariusz Tytko z Uniwersytetu Jagiellońskiego, który zatytułował swoje wystąpienie następująco: Wychowanie moralne - kształcenie charakteru dziecka (ujęcie realistyczne).

Na zakończenie trzeciej sesji o zabranie głosu została poproszona Janina Kostkiewicz, która skrótowo przedstawiła temat: Pedagogika realistyczna $w$ Polsce. Tradycja i perspektywy. Jej zdaniem myśl realistyczna miała do tej pory niejako mniejsze szczęście w polskim życiu akademickim. Tę tezę mówczyni zobrazowała wynikami swoich badań nad dziejami pedagogiki kultury w Polsce. J. Kostkiewicz odkryła w dorobku pedagogiki katolickiej autorów, którzy z pozycji neotomizmu zajmowali się tą problematyką. Jednak w dotychczasowych opracowaniach nie wspomina się o nich ani słowem. To milczenie daje, zdaniem J. Kostkiewicz, asumpt do świadomego inicjowania badań mających na celu niwelowania powstałych (świadomie lub nieświadomie) luk w wiedzy pedagogicznej i do przypominania dorobku zapomnianych polskich autorów. Dziwnym trafem młodzi badacze wykazują w tym zakresie większe zainteresowanie niż ci, których „białe plamy” w jakimś sensie osobiście dotyczą.

Po tych wystąpieniach odbyła się druga dyskusja panelowa. Jej głównym przedmiotem było poszukiwanie tematu na trzecie spotkanie seminaryjne. Zabierający głos zgodnie uznali potrzebę dalszego penetrowania polskiej myśli pedagogicznej i wydobywania z niej zapomnianych autorów i ich dzieł. Ustalenie tematu kolejnego seminarium odłożono jednak na późniejszy czas. 